\title{
GUA SONG AGUNG DI PACITAN: STUDI PENDAHULUAN TENTANG TEMUAN DAN MASA HUNIANNYA
}

\section{Goenadi Nitihaminoto}

Keywords: Pacitan; Song Agung; Prehistory; Archaeology; Artifacts

\section{How to Cite:}

Nitihaminoto, G. (1988). Gua Song Agung di Pacitan: Studi Pendahuluan Tentang Temuan dan Masa Huniannya. Berkala Arkeologi, 9(2), 13-31. https://doi.org/10.30883/jba.v9i2.527

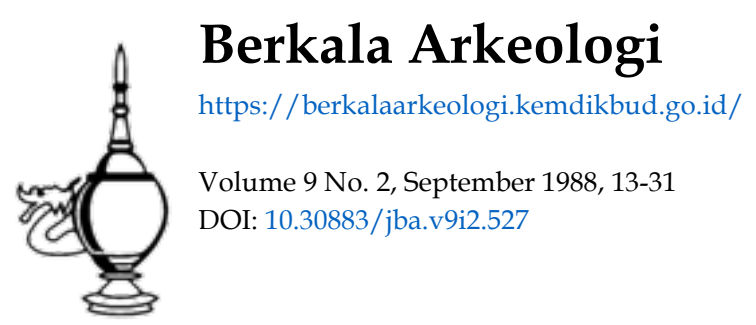




\section{GUA SONG AGUNG DI PUNUNG, PACITAN : STUDI PENDAHLUAN TENTANG TEMUAN DAN MASA HUNIANNYA}

Oleh :

Goenadi Nitihaminoto

\section{PENDAHLLUAN}

Sebagian besar situs arkeologi di daerah Pacitar, Jawa Timur terletak di Kecamatan Punung. Di daerah ini ditemukan artefak-artefak yang hampir mewakili seluruh periodisasi prasejarah di Indonesia. Temuan alatalat batu paleolitik ditemukan di Kali Baksoka, dan beberapa sungai di daerah Tabuhan. Temuan-temuan dari masa yang lebih muda ditemukan pula di lembah Kali Baksoka, Ngrijangan, Teleng dan Gua Songterus di Tabuhan.

Alat-alat batu paleolitik di sekitar Kali BAksoka, banyak mengundang pendapat beberapa ahli. Von Koenigswald misalnya, menduga bahwa alat-alat batu di sekitar Kali Baksoka berusia Plestosin Tengah. Penelitian di lembah Kali Baksoka, di dekat desa Janglot, Jan di dasar Kali Ngambar, anak Kali Baksoka, ditemukan alat-alat batu paleolitik dari dasar sungai tersebut (R.P. Soejono, 1984: 47-93).

Di daerah Tabuhan, jenis-jenis alat budaya Pacitan ditemukan di lembah-lembah Kali Gede, Kali Sunglon dan Kali Sirikan yang merupakan sungai-sungai bawah tanah. Alat-alat paleolitik yang ditemukan setaraf dengan alat-alat batu yang ditemukan di lembah Kali Baksoka. Penemuan itu terjadi pada tahun 1953 dan tahun 1954 yang dilakukan oleh Van Heekeren, R.P. Soejono, dan Basoeki (R.P. Soejono, 1984: 92-94; Van Heekeren, 1954: 9-10). 
Endapan-endapan di tebing Kali Baksoka selain mengandung artefak-artefak budaya Pacitan, ditemukan pula alat-alat batu neolitik. Alat-alat batu neolitik ini berupa plank beliung persegi (G.J. Bartstra, 1976: 4546; 75).

Di sekitar Desa Tabuhan, yang terletak kurang lebih $6 \mathrm{~km}$ barat laut Punung, telah dilaksanakan ekskavasi di Gua Songterus (Tabuhan) pada tahun 1953, untuk mencari alat-alat paleolitik. Akan tetapi hasilhasil yang diperoleh berupa perkakas-perkakas neolitik, di antaranya terdapat beberapa alat yang diserpih dari suatu jenis kapak paleolitik dan sisa-sisa tulang binatang yaitu tengkorak-tengkorak monyet dan geligih gajah (Elephas maximus) (R.P. Soejono, 1984: 93).

Van Stein Callenfels pada tahun 1927, telah mengadakan penelitian di daerah sekitar Pacitan dan Punung. Dalam penelitian itu ditemukan lebih dari seratus situs neolitik, beberapa di antaranya mengandung mata panah, yang mempunyai kesamaan dengan tipe anak panah dari Gua Lawa di daerah Bojonegoro. Temuan lain berupa beliung persegi yang belum diupam berjumlah sangat banyak (Von Heine-Geldern, 1945: 134). Dalam penelitian akhir-akhir ini Balai Arkeologi Yogyakarta mengadakan penelitian ulang di satu situs di antara situs-situs yang diberitakan oleh Van Stein Callenfels tersebut, yaitu situs Ngrijangan yang terletak di desa Sooka, Kecamatan Punung.

Situs Ngrijangan diteliti oleh Balai ARkeologi Yogyakarta pada tahun 1988, dipimpin oleh Harry Widianto. Situs tersebut terletak sekitar $3 \mathrm{~km}$ di sebelah utara Punung. Hasil penelitian di situs ini dapat disimpulkan bahwa situs Ngrijangan merupakan bengkel tradisi neolitik yang memproduksi beliung persegi dari batu tufa kersikan (silicified tuff) dan batu pasir kersikan (silicified-sandatone) (Harry Widianto, 1989).

Muhammad Heydar pada tahun 1986 mengadakan penelitian di situs Teleng, yang terletak sekitar $4 \mathrm{~km}$ 
di sebelah barat daya situs Ngrijangan. Dalam penelitian itu ditemukan beberapa beliung persegi yang belum diupam. Dalam kesimpulan dikatakan bahwa situs Teleng merupakan situs perbengkelan neolitik. Teknologi pembuatannya menunjukkan adanya empat tahap pengerjaan (Muhamad Heydar, 1989: 122-125).

Dari data yang terurai di atas tampak bahwa situs mesolitik belum pernah disebut-sebut. Oleh sebab itu, menarik sekali apabila disebutkan bahwa Von Koeningswald pada tahun 1936 pernah mengadakan penelitian di daerah Punung, yaitu di suatu gua dekat Gunung Cantelan. Lebih-lebih dikatakan bahwa dari situs itu mengandung budaya mesolitik, meskipun Koenigwald sendiri belum pernah menerbitkan laporannya secara lengkap (D.P. Erdbrink, 1954: 297).

Bertolak dari berita yang disampaikan oleh Erdbrink tersebut di atas, dan terdorong oleh rasa ingin tahu, maka saya memutuskan untuk meninjau situs tersebut pada tanggal 11 Pebruari 1989. Kebetulan pada waktu itu Dr. Harry Allen dari Anthropology Department University of Auckland, New Zealand menaruh perhatian yang sama, sehingga kunjungan ke situs dilakukan bersama.

Di permukaan tanah lantai gua tidak ditemukan tanda-tanda kehidupan. Oleh karena itu dilakukan pengorekan permukaan tanah untuk memperoleh sisa-sisa kehidupan yang pernah ada di gua ini. Pengorekan dilakukan di dua tempat, yaitu di tengah dan di bagian kiri mulut gua tersebut. Kedua tempat itu dikorek tidak lebih 0,50 meter persegi dan dalamnya kurang dari 10 $\mathrm{cm}$. Dari kegiatan ini ditemukan tatal batu, beberapa pecahan tulang dan kereweng (pecahan gerabah). Kegiatan pengumpulan data kehidupan ini tidak diperluas karena takut merusak situs terlalu banyak.

Beberapa di antara tatal-tatal batu yang dikumpulkan mempunyai ciri alat yang pernah dipakai di masa lalu. Tulang-tulang yang dikumpulkan tampaknya berasal 
dari ukuran besar, sedang dan kecil. Tulang-tulang yang berukuran besar tidak ada yang utuh, semua telah pecah menjadi kepingan-kepingan kecil. Tulang-tulang berukuran sedang tidak pecah, tetapi patah, sedangkan tulang berukuran kecil dalam keadaan patah pula. Tulang-tulang berukuran besar dan kecil tampaknya mempunyai tingkat kekerasan sama, sedangkan tulang berukuran sedang tampak lebih lunak dibandingkar, tulangtulang lainnya. Kereweng yang ditemukan berwarna abuabu gelap dan berukuran tebal.

Data artefak dan ekofak yang telah dikumpulkan tersebut merupakan tanda bahwa gua itu pernah dihuni di masa lampau. Berdasarkan atas keadaan artefak dan ekofak yang mempunyai perbedaan jenis, bentuk dan ukuran tersebut, dapat diperkirakan bahwa perbedaanperbedaan itu berkaitan dengan masa hunian yang berbeda pula. Dengan demikian apakah gua ini pernah dihuni oleh manusia dalam beberapa periode waktu yang berlainan?

Identifikasi pecahan tulang untuk mengetahui jenis dan tingkat (fosilisasi) dilakukan oleh dokter S. Boedhisampoerno dari Laboratorium Bio-Paleoantropologi Yogyakarta. Tatal-tatal batu diidentifikasi oleh Harry Widianto untuk mengetahui ciri kealatannya dan perkiraan waktu pembuatannya. Identifikasi kereweng yang dilakukan untuk memperoleh gambaran bentuk dan teknologi yang berkaitan dengan waktu pembuatannya, dilakukan oleh penulis. Identifikasi keramik asing dilakukan oleh Abu Ridho.

\section{RIWAYAT PENELITIAN}

Dalam ekskavasi yang dilakukan di sebuah gua dekat Gunung Cantelan, Von Koenigswald telah menemukan beberapa artefak dan ekofak. Artefak-artefak yang ditemukan antara lain berupa alat serpih batu api, beberapa batu pukul dari andesit dan trachyte, mata panah, dan batu-batu giling (milling stone), Beberapa 
ekofak yang ditemukan antara lain pecahan tulang dan gigi binatang, gigi manusia, pecahan kulit siput dan kerang. Pecahan-pecahan gerabah, beliung persegi yang diupam, dan mata panah neolitik tidak ditemukan di situs ini (D.P. Erdbrink, 1954: 297-298).

Berdasarkan data dari Von Koenigswald itu, Erdbrink membuat analisis temuan. Hasil analisis itu menunjukkan bahwa serpih mata panah, dan batu giling mempunyai persamaan erat dengan temuan sejenis dari Gua Lawa di Sampung. Dikatakan bahwa mata panah berdasar bulat merupakan mata panah primitif yang berasal dari budaya mesolitik, sedangkan mata panah dengan dasar berbentuk huruf $V$ terbalik merupakan ciri neolitik. Di situs gua ini tidak ditemukan mata panah yang berciri neolitik. Selain itu ditemukan lancipanlancipan dan alat-alat batu yang menyerupai serut (Gambar 3).
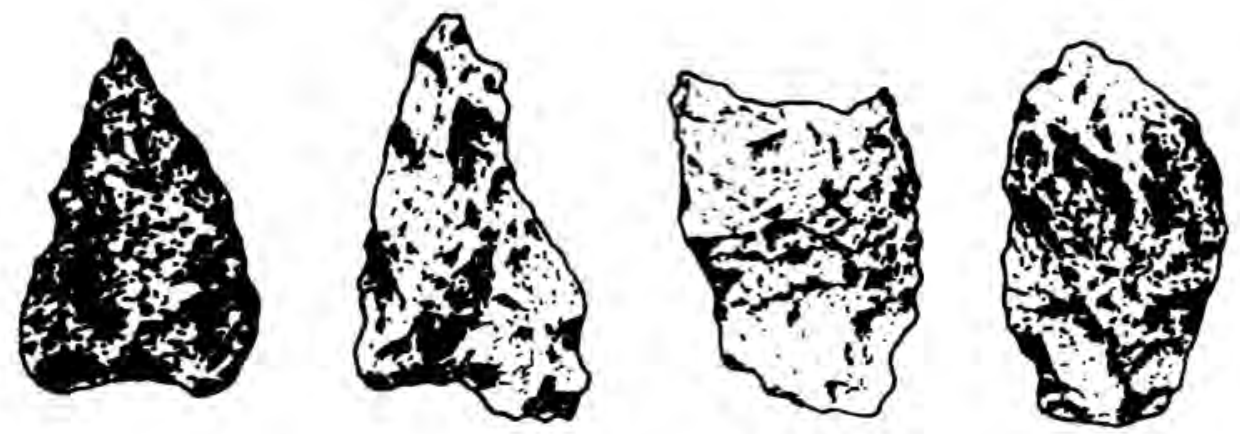

0

$5 \mathrm{~cm}$

Gambar 3. Alat-alat batu menyerupai serut dari daerah Gunung Cantelan (D.P. Erdbrink 1954).

Gigi manusia yang ditemukan dari situs ini, setelah dibandingkan dengan hasil analisis yang dilakukan oleh Mijsberg terhadap temuan yang sama dari Gua Lawa di Sampung, mempunyai persamaan menonjol. Tidak ditemukannya mata panah berciri neolitik, beliung persegi yang diupam, dan pecahan gerabah, maka Erdbrink sampai pada suatu kesimpulan bahwa manusia dan buda- 
ya dari ini, sejaman dengan manusia dan budaya dan Gua Lawa di Sampung, yaitu berasal dari tingkatan mesolitik (D.P. Erdbrink, 1954: 297-298).

Berpuluh tahun kemudian gua itu tidak dijamah oleh para ahli. Menurut informasi dari Sokiran dan Teguh, petugas dari Departemen Pendidikan dan Kebudayaan Kecamatan Punung, dikatakan bahwa pada sekitar tahun 1975 gua in pernah diteliti oleh petugas dari ITB. Penelitian itu berlangsung selama kurang lebih satu minggu, dengan mengadakan penggalian. Selanjutnya diinformasikan pula bahwa para peneliti bekerja untuk mengumpulkan tulang-tulang dari gua tersebut. Departemen Pendidikan dan Kebudayaan Kecamatan Punung belum memperoleh laporan dari kegiatan tersebut.

\section{HASIL PENGAMATAN}

Terdapat dua buah gua di dekat Gunung Cantelan. Gua pertama adalah sebuah gua (cave) kecil yang terletak di kaki gunung itu, sedang gua yang ke dua terletak di sebelah timur gunung berupa sebuah ceruk gua (rockshelter). Gua pertama memang layak untuk dihuni, tetapi hanya untuk beberapa individu saja.Selain itu, pada permukaan dan sub permukaannya tidak ditemukan sisa-sisa kehidupan. Oleh karenanya dapat disimpulkan bahwa gua pertama yang dikunjungi ini bukan gua yang dimaksudkan oleh Erdbrink, karena bukan rockshelter, dan selain itu tidak ditemukan tanda-tanda kehidupan di dalamnya.

Lalu diputuskan untuk mencari kemungkinan adanya gua lain di sekeliling bukit, karena gua itu diperkirakan bukan tempat yang sedang dicari. Usaha pencarian gua di sekeliling bukit tidak mendapat hasil yang diharapkan karena tidak mendapatkan gua yang layak dihuni. Kemudian pencarian (dilanjutkan) ke arah timur Gunung Cantelan untuk menilai keterangan penduduk tentang keadaan gua yang diinformasikan itu. Gua ini oleh penduduk setempat disebut Song Agung, merupakan sebuah rockshelter berukuran besar. 
Song Agung terletak sekitar 250 meter di sebelah timur Gunung Cantelan. Gua ini menghadap ke timur. Sekitar 200 meter di sebelah timur gua mengalir sebuah sungai, yaitu anak Kali Nampol. Arah hadap suatu tempat maupun adanya sumber air, merupakan faktor yang sangat diperhitungkan dalam melakukan suatu hunian. Berdasarkan atas kenyataan-kenyataan itu, maka saya dan Harry Allen sepakat bahwa Song Agung adalah rockshelter yang dimaksudkan oleh Erdbrink maupun Von Koenigswald.

Pengamatan yang dilakukan terhadap gua ini diperoleh kesan bahwa Song Agung merupakan sebuah rockshelter besar. Lebar mulut gua 27 meter, lebar ceruk 7 meter, dan tingginya sekitar 10 meter. Di depan mulut gua masih terdapat dataran, sehingga luas keseluruhan dataran sebagai lantai gua sekitar 200 meter persegi. Dataran gua ini terletak sekitar 2 meter di atas lahan pertanian yang terbentang di depannya. Keadaan lantai gua ini datar dan besar. Keadaan gua cukup kering, meskipun dalam musim hujan. Iklim segar yang terdapat di dalam gua dan di sekelilingnya berasal dari Gunung Cantelan yang berketinggian 378 meter di atas permukaan laut.

Secara administratif Song Agung terletak di Dukuh Klepu, Kelurahan Punung, Kecamatan Punung, Kabupaten Pacitan, Jawa Timur. Situs ini berada sekitar $3 \mathrm{~km}$ di sebelah tenggara Punung, atau sekitar $30 \mathrm{~km}$ di sebelah barat laut Pacitan. Secara geografis situs ini terletak antara $4^{\circ} 13^{\prime} 24,8^{\prime \prime}$ Bujur Timur dan $8^{\circ} 8^{\prime} 30,81^{\prime \prime}$ Lintang Selatan, meredian Jakarta (Gambar 1).

Berkala Arkeologi IX (2)

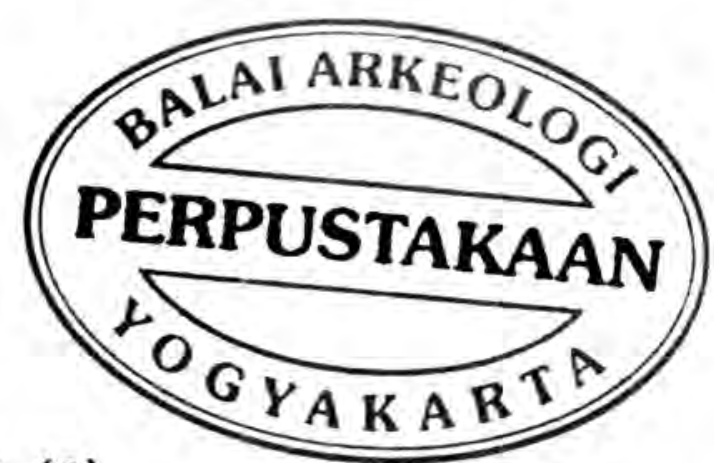




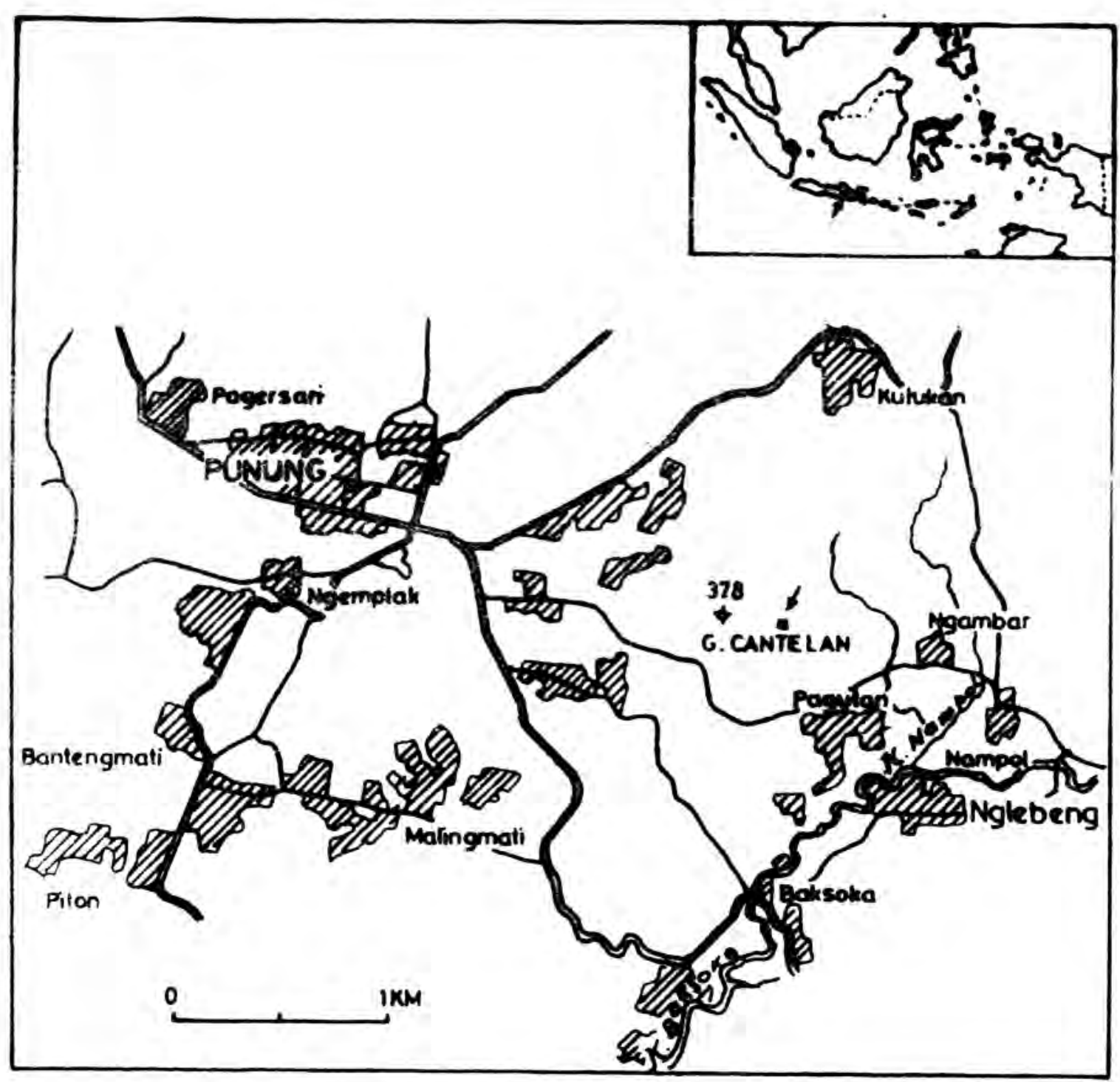

Gambar 1. Lokasi Gua Song Agung di Punung, Pacitan (Jawa Timur).

\section{Temuan}

Jenis temuan yang berhasil dikumpulkan dari situs ini, terdiri atas 5 macam, yaitu tatal batu, kereweng, pecahan keramik asing, pecahan tulang, dan pecahan kerang. Tatal batu yang dikumpulkan berjumlah 33 potong, kereweng 1 potong, pecahan keramik asing 1 potong, pecahan tulang 26 potong, dan pecahan kerang 2 potong. Setelah diadakan identifikasi pada temuan-temuan itu diperoleh hasil-hasil seperti berikut di bawah ini. 


\section{Alat serpih dan bilah}

Dari tatal batu yang berjumlah 33 potong setelah diidentifikasi hanya ditemukan dua potong yang diperkirakan sebagai alat. Kedua potong tatal yang diperkirakan sebagai alat tersebut diidentifikasikan sebagai alat serpih dan bilah (Gambar 2).
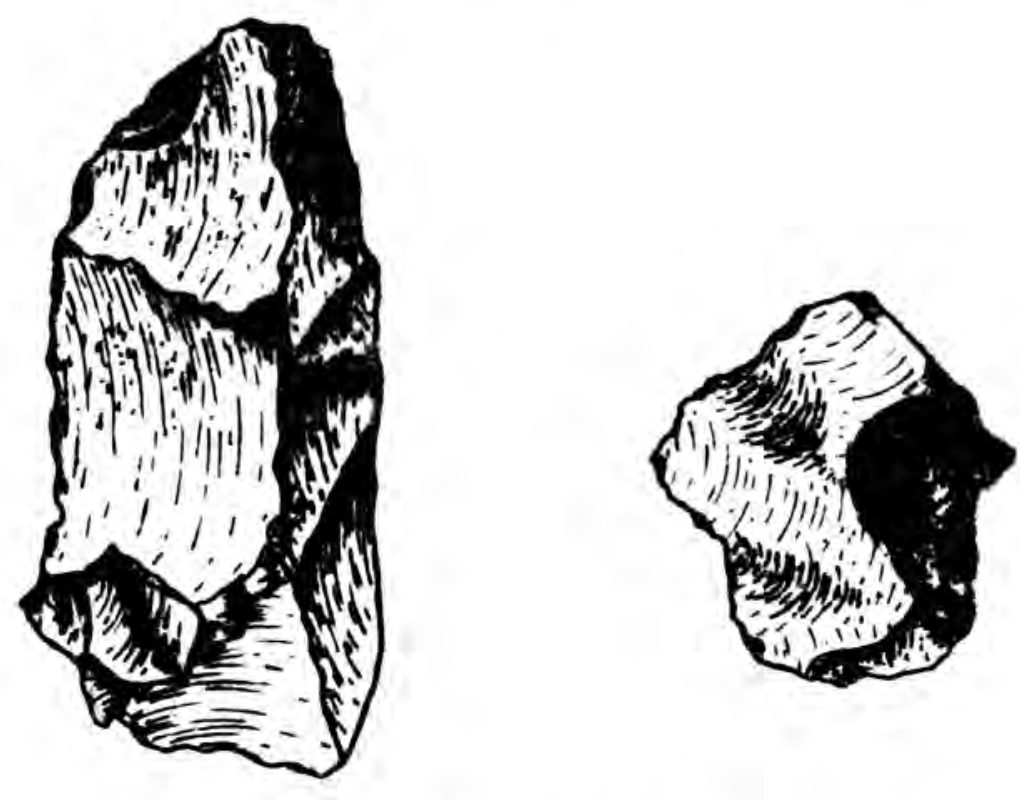

Gambar 2. Alat bilah dan alat serpih (kanan), dari Gua Song Agung.

\section{Alat Serpih (flake)}

Alat ini bentuknya pipih melebar, tidak beraturan. Bahan pembuatnya mungkin dari tufa kersikan (silicified tuff). Panjang alat $2,9 \mathrm{~cm}$, dan tebal $0,6 \mathrm{~cm}$, merupakan sebuah alat serpih yang dipersiapkan (prepared flake). Tidak ditemukan kulit batu (cortex), baik di bagian dorsal maupun ventralnya. Bagian dorsal menunjukkan adanya tiga bulbus negatif, berupa faset-faset melebar dan memanjang. Di bagian ventral tidak ditemukan bulbus negatif, kecuali adanya alur-alur penyerpihan (ripples) yang arahnya mengikuti ukuran panjang dataran pukulnya. Di bawah dataran pukul, masih di bagian ventral, terdapat bulbus yang cukup jelas. 
Hampir seluruh sisinya, kecuali dataran pukul, menunjukkan adanya perimping (bekas pakai). Pola-pola perimping menunjukkan bahwa alat serpih ini telah dipergunakan pada dua mukanya, baik pada bagian dorsal maupun pada bagian ventralnya. Intensitas pemakaian alat ini cukup lanjut.

\section{Alat Bilah (blade) (?)}

Alat ini bentuknya memanjang, berpenampang iris segitiga. Bahan pembuatnya mungkin dari batu gamping kersikan (silicified limestone)). Panjang 5,1 cm, lebar $2,5 \mathrm{~cm}$ dan tebal $1,3 \mathrm{~cm}$. Bagian dorsal alat ini didominasi oleh dua faset panjang akibat pemangkasan memanjang (longitudinal chipping). Kedua faset tersebut bertemu dan membentuk igir yang sejajar dengan sisi panjangnya. Pada masing-masing faset minimal ditemukan tiga bulbus negatif. Bagian ventral-polos, tidak dite-mukan bulbus negatif.

Alur penyerpihan (ripples) maupun retak penyerpihan (fissures) tidak terlihat. Pada salah satu ujungnya terdapat dataran pukul (striking platform) sempit, tetapi tidak menunjukkan adanya bulbus (bulb of percussion). Salah satu sisi panjang alat ini, mulai dari dataran pukul ke ujungnya, terdapat perimping berpola kasar, sehingga diduga intensitas pemakaiannya belum lanjut. Tingkatan patinasi cukup lanjut (heavy patinated).

\section{Fragmen Keramik Asing}

Fragmen keramik asing yang ditemukan berjumlah satu potong, berukuran kecil. Panjang $2,0 \mathrm{~cm}$, lebar 1,4 $\mathrm{cm}$, dan tebalnya $0,3 \mathrm{~cm}$. Pecahan ini berasal dari bentuk piring kecil, diameter $14 \mathrm{~cm}$, tinggi $3,5 \mathrm{~cm}$. Piring kecil ini terbuat dari bahan batuan (stone ware), warna abu-abu kecoklatan. Glasir berwarna hijau kekuningan, mengkilat, tipis dan melapis bagian-bagian muka dan belakang. Keramik itu berasal dari dinasti Song Akhir, pada akhir abad $13 \mathrm{M}$ dari daerah Cina Selatan. 
Fungsi keramik tersebut untukmencukupi kepentingan sehari-hari dan kadang-kadang dipergunakan sebagai wadah sesaji.

\section{Kereweng}

Kereweng yang ditemukan berjumlah satu potong, berukuran kecil. Panjang $2,4 \mathrm{~cm}$, lebar $1,4 \mathrm{~cm}$, dan tebal $0,5 \mathrm{~cm}$. Bagian luar berwarna abu-abu gelap kecoklatan, sedangkan bagian dalamnya berwarna abu-abu kehitaman. Teknik pembuatannya menunjukkan penggunaan roda putaran (potter's wheel). Kereweng ini berasal dari pecahan gerabah yang mungkin berupa mangkuk berdasar bulat. Dilihat dari ciri-ciri fisik yang ada, tampaknya kereweng ini merupakan kereweng kuna. Setelah dianalisis maka bahan pembuatnya terdiri atas $88,19 \%$ tanah liat, $9,92 \%$ pasir dan 1,85\% kapur. Tirigkat porositasnya tidak terlalu tinggi yaitu $19,38 \%$.

\section{Fragmen tulang}

Jumlah pecahan tulang yang ditemukan sebanyak $=26$ potong. Setelah dilakukan identifikasi, diketahui bahwa 17 potong telah memfosil, sedangkan sisanya 7 potong masih berupa sub fosil. Tujuh belas potong fosil tulang tersebut, 15 potong di antaranya berukuran besar, sedangkan dua potong lainnya berukuran kecil. Tujuh potong tulang lainnya yang masih merupakan sub fosil merupakan pecahan tulang manusia.

\section{Fosil tulang hewan}

Di antara 17 potong fosil tulang tersebut, 15 potong berupa fosil tulang bovidae (kerbau, sapi) dan ursidae (beruang), dan dua potong fosil tulang lainnya berupa tulang primates (macaca sp). Fosil tulang bovidae dan ursidae keadaannya sangat fragmentar. Pemecahan tulang ini sangat intensif, tampak seperti disengaja. Fosil tulang macaca sp berupa pecahan tulang rahang bawah bagian kiri dan bagian kanan. Pecahan tulang 
rahang bawah kiri terdapat dua gigi geraham, sedangkan pecahan tulang rahang bawah kanan dijumpai tiga gigi geraham yang masih melekat.

\section{Sub-fosil tulang manusia}

Sub fosil tulang manusia terdiri atas 7 potong, terdiri atas 4 potong distal tulang hasta (ulna), 2 potong tulang iga, dan 1 potong tulang pengumpil (radius). Identifikasi tulang manusia tersebut belum lanjut, karena belum diketahui jenis kelamin, umur, tinggi badan, ras dan sebab-sebab kematian.

\section{Fragmen kerang}

Dua fragmen kerang berukuran kecil, dari jenis Pelecypoda. Keduanya telah mengalami proses fosilisasi. Satu di antaranya tampak jauh lebih tua, mungkin bersamaan dengan pengangkatan daerah itu atau bersamaan dengan turunnya air laut. Satu potong kerang lainnya juga telah memfosil tetapi tidak seintensif potongan kerang yang pertama. Mungkin kerang ini sejaman dengan tulang-tulang hewan yang memfosil tersebut.

\section{BEBERAPA PENDAPAT}

\section{Alat batu}

Dalam konteks teknologi alat-alat batu (lithic technology), kedua jenis alat dari Song Agung tersebut termasuk dalam katagori alat non masif. Hampir dapat dipastikan bahwa keduanya merupakan hasil serpihan tangan manusia, karena masing-masing alat mempunyai dorsal dengan beberapa faset penyerpihan pembentukan, dan mempunyai bagian ventral polos. Adanya dataran pukul pada kedua alat tersebut menunjukkan bahwa pelepasan tatal dari batu induknya dilakukan melalui teknik pemangkasan tidak langsung (indirect percusion) dengan memakai alat penghubung (fabricator) dan batu pukul (hammer stone). 
Untuk menentukan tingkatan teknologi alat tersebut ke dalam periodisasi -- baik paleolitik, mesolitik, maupun neolitik --, merupakan masalah sendiri yang cukup menarik. Hal ini disebabkan oleh adanya dua faktor terkait, yaitu lokasi penemuan dan adanya tradisi teknologi yang mampu menembus batas-batas teoritis periodisasi. Sejauh ini, daerah Punung telah memberikan himpunan data alat batu dari tingkatan paieolitik dan neolitik. Di lain pihak, secara teoritis teknologis, alatalat serpih-bilah paleolitik mampu menembus batas mesolitik sebagai alat serpih-bilah mesolitik, dan bahkan eksistensinya mampu hadir sebagai tatal-tatal batu (chips) yang muncul sebagai limbah produksi (debitage) pembuatan beliung persegi neolitik.

Ketiga jenis alat di atas, yaitu alat serpih bilah paleolitik, alat serpih-bilah mesolitik, dan tatal-tatal neolitik, mempunyai ciri-ciri teknologi sama karena umumnya dibuat dari batu berkadar silika tinggi dengan teknik pembuatan sama pula. Ciri-ciri teknologis seperti dataran pukul, bulbus, bagian dorsal berfaset dan bagian ventral tanpa faset, berkaitan erat dengan teknik pelepasan dari batuan induknya melalui pemangkasan tidak langsung, sedangkan tatu, retak danalur penyerpihan berkaitan dengan kerasnya bahan karena berkadar silika tinggi.

Dengan memperhatikan lokasi penemuan dari daerah Punung dan ciri-ciri teknologinya, ke dua alat dari Song Agung tersebut mempunyai kesempatan sama untuk dianggap sebagai alat serpih dan bilah paleolitik, alat serpih dan bilah mesolitik, maupun tatal-tatal dipakai (utilized-chips) sebagai limbah produksi beliung persegi neolitik. Dari segi lingkungan, terutama tempat kedua alat itu ditemukan adalah rockshelter, maka kemungkinan kedua alat tersebut dapat diperkirakan sebagai produk budaya mesolitik. Hal inipun belum dapat dijadikan pedoman, karena lingkungan gua semacam itu, Gua Songterus (Tabuhan) misalnya, banyak ditemukan budaya neolitik. Untuk menentukan periodisasi alat tersebut, 
harus dilihat konteksnya dengan temuan-temuan lainnya.

\section{Fragmen keramik asing}

Dari ukuran dinding keramik yang relatif tipis, pecahan ini dapat diduga berasal dari piring. Berdasarkan ciri-ciri fisik lainnya seperti bahan pembuatannya serta glasir yang ada menunjukkan ciri-ciri dari pabrik keramik di Cina Selatan, berasal dari dinasti Song Akhir dari abad $13 \mathrm{M}$. Dengan demikian maka keramik asing ini merupakan keramik kuna, karena umurnya sampai sekarang telah mencapai 700 tahun lebih.

Keramik Cina ini diperkirakan sebagai wadah upacara karena pada waktu itu jumlah keramik ini tidak banyak, sehingga dianggap sebagai barang mewah. Selain dipergunakan untuk lambang status sosial, karena keistimewaannya dapat pula dipergunakan sebagai wadah upacara. Dikatakan bahwa keramik semacam ini pernah ditemukan di Trowulan Tuban, Kepanjen (Malang Selatan), Sulawesi Selatan, Werluka (Flores Barat), Muara Jambi, Kota Cina (Medan), Aceh, dan Kalimantan Barat.

\section{Kereweng}

Jumlah temuan kurang meyakinkan karena hanya satu potong, yang ditemukan di sub permukaan. Temuan ini dapat diduga sebagai temuan baru, tetapi dapat pula diduga sebagai kereweng kuna. Apabila kereweng ini berasal dari pecahan periuk baru, maka sampel yang ditemukan di gua tersebut harusnya lebih banyak karena intensitas pemakaiannya lebih tinggi.

Bila kereweng ini kuna, harusnya sudah disebutsebut oleh D.P. Erdbrink. Erdbrink (1954) mengatakan bahwa kereweng tidak pernah ditemukan. Dilihat dari teknologinya, kereweng ini dihasilkan dari teknik pembuatan dengan menggunakan roda putar (potter's wheel). 
Pembuatan gerabah dengan teknik ini tidak berarti bahwa gerabah itu berasal dari masa-masa yang lebih muda, karena ciri-ciri fisiknya merupakan kereweng kuna.

Analisis terhadap bahan pembuatannya tidak banyak menolong untuk menentukan tingkat usianya, karena belum ada referensi persentase unsur yang lengkap yang mengacu kepada umur atau tingkat periodisasinya. Oleh karena itu berdasarkan ciri-ciri fisik seperti warna, dan tanda-tanda fisik lain seperti bentuk, patinasi, dan setelah dibandingkan dengan kereweng-kereweng yang kuna dan baru, ciri-ciri fisik tersebut banyak persamaannya dengan kereweng kuna. Mungkin kereweng ini seumur dengan pecahan keramik asing yang ditemukan bersama dengan kereweng tersebut, yaitu berasal dari abad $13 \mathrm{M}$. Mungkin pula kereweng ini tidak seumur dengan sub-fosil tulang manusia, sehingga umurnya lebih muda dari sub sub-fosil tulang manusia tersebut.

Kereweng tersebut diperkirakan berasal dari bentuk mangkuk berdasar bulat. Dilihat dari tingkat parositasnya rendah maka mangkuk tersebut digunakan sebagai wadah air. Mungkin mangkuk ini merupakan pelengkap upacara, seperti halnya piring keramik Cina tersebut.

\section{Fosil tulang hewan}

Proses fosilisasi adalah proses penggantian unsurunsur organik menjadi unsur-unsur anorganik yang berasal dari lingkungan tempat benda itu berada. Proses perubahan itu paling sedikit memerlukan waktu 7.000 tahun. 1) Berdasarkan hal itu maka fosil-fosil hewan yang ditemukan di gua ini minimal dapat ditanggali dari waktu tersebut, yaitu 7000 tahun atau lebih. Apabila waktu tersebut dikembalikan ke belakang, maka dapat dimasukkan dalam Masa Berburu dan Mengumpul Makanan Tingkat Lanjut, dengan budaya mesolitik di dalamnya.

1) Konsultasi pribadi dengan Prof. Dr. T. Jacob. 
Bila dilihat dari jenis hewannya yaitu bovidee, ursidae, dan macaca ep, maka habitatnya adalah hutan dan padang rumput. Bovidae dapat hidup di hutan ataupun di padang rumput. Macaca ep dan ursidae, hidup dalam hutan. Habitat seperti ini tampaknya masih sesuai dengan keadaan lingkungan gua Song Agung, sehingga hewan-hewan tersebut dapat diduga berasal dari daerah di sekitar gua Song Agung sendiri.

Karena tulang hewan tersebut ditemukan di gua Song Agung dalam keadaan terpecah-pecah seperti disengaja, maka diduga bahwa hewan-hewan tersebut dijadikan salah satu bahan makanan penghuni gua yang hidup pada masa berburu dan mengumpul makanan tingkat lanjut. Perkiraan ini didasari oleh adanya kenyataan bahwa tulang-tulang tersebut dipecah sebelum mengalami proses fosilisasi.

Penghuni gua ini adalah manusia yang hidup semasa dengan fosil-fosil tulang tersebut. Tampaknya temuan gigi manusia dari situs ini berasal dari gigi penghuni gua tersebut karena mempunyai ciri sama dengan temuan gigi manusia dari Gua Lawa, Sampung (Erdbrink, 1954). Salah satu budaya penghuni gua ini adalah mata panah yang berdasar bulat. Dengan demikian sub-fosil tulang manusia yang ditemukan dari gua ini bukan penghuni pertama gua Song Agung, karena penghuni pertama telah ditemukan fragmen giginya.

\section{Sub-fosil tulang manusia}

Waktu-waktu yang diperlukan supaya suatu benda organik menjadi sub-fosil belum diketahui dengan pasti. T. Jacob memperkirakan bahwa untuk tingkat sub-fosil tersebut, dibutuhkan waktu sekitar 5000 tahun 2 ), dengan demikian tingkat ini memerlukan waktu kurang dari 7000 tahun. Apabila perkiraan itu benar, maka tulangtulang manusia yang berupa sub fosil tersebut merupakan penghuni gua Song Agung sesudah penghuni pertama yang berasal dari 7000 tahun yang lalu.

2)Konsultasi pribadi dengan Prof. Dr. T. Jacob. 
Masa sesudah 7000 tahun adalah Masa Bercocok Tanam dengan budaya neolitik. Masa ini di Indonesia berkisar antara $3500-2500 \mathrm{BC}$ atau antara $5500-4500$ tahun yang lalu (Van Heekeren, 1972: 154). Dengan demikian dapat diduga bahwa kedua alat batu yang ditemukan di gua tersebut (Gambar 2), yaitu alat serpih dan alat bilah merupakan budaya dari penghunian gua yang kedua, yang-tulangnya masih berupa sub fosil.

\section{Pecahan keramik asing dan kereweng}

Kereweng dan fragmen keramik asing yang ditemukan mungkin berasal dari waktu yang sama. Kedua temuan ini merupakan bukti adanya kehidupan di gua tersebut. Kedua temuan itu berasal dari waktu yang lebih muda yaitu abad $13 \mathrm{M}$. Bila demikian halnya maka mungkin terdapat penghunian lagi, sesudah penghunian yang kedua tersebut. Bagaimana bentuk hunian itu dan sampai kapan penghunian itu berlangsung, belum dapat diketahui dengan pasti.

Tetapi apabila perkiraan fungsi gerabah dan keramik itu betul, sebagai wadah upacara (sesajian), maka pada abad $13 \mathrm{M}$ tersebut orang masih sering datang ke gua itu untuk melakukan sesaji. Sesaji ini perlu dilakukan karena di kalangan masyarakat waktu itu mungkin terdapat kepercayaan bahwa gua ini ada penunggunya, sehingga perlu diberi sesaji supaya jangan marah. Dapat juga mereka beranggapan bahwa gua tersebut merupakan tempat: roh nenek moyang mereka, sehingga perlu diberi sesaji sebagai sarana penghormatan.

\section{KESIMPULAN}

Song Agung adalah rockshelter yang dimaksudkan oleh D.P. Erdbrink, karena gua tersebut sesuai dengan deskripsi yang diuraikannya. Gua ini paling layak dipakai sebagai tempat hunian di masa lampau dengan bukti-bukti kehidupan yang ditinggalkannya. Gua lain yang setaraf dan seindah Song Agung tidak ditèmukan di 
daerah itu. Kelaikan tinggal seperti arah hadap, keadaan dalam gua, sumber air, dan iklim semuaniya ada pada gua ini.

Dari bukti-bukti adanya temuan alat-alat batu, fosil tulang hewan, sub-fosil tulang manusia, dan artefak-artefak lain menunjukkan adanya perbedaan waktu yang menyolok antara satu temuan dengan temuan lainnya.

Berdasarkan kenyataan itu maka dapat diperkirakan bahwa Song Agung pernah dihuni dalam tingkatan waktu yang berbeda. Mungkin kehidupan itu terjadi sejak masa berburu dan mengumpul makanan tingkat lanjut, kemudian dilanjutkan pada waktu sesudahnya, yaitu pada masa bercocok tanam. Mungkin hunian di Song Agung ini berlanjut lagi sampai Masa Bercocok Tanam berakhir.

Masa hunian sesudah Masa Bercocok Tanam mungkin dimulai pada abad $13 \mathrm{M}$, atau masa bercocok tanam di daerah itu belum dapat diketahui dengan pasti. Mereka mungkin tidak menetap di dalam gua lagi melainkan tinggal di luar gua. Pada saat tertentu mereka datang ke gua itu untuk memberikan sesaji, sebagai penghormatan terhadap penghuni atauroh nenek moyang yang dianggap tinggal di dalam gua.

Mengingat data kehidupan yang dikumpulkan dari gua ini belum banyak, maka penelitian di situs ini perlu dilakukan secara intensif, sehingga data kehidupan akan dapat disusun lebih mantap lagi. 


\section{DAFTAR PUSTAKA}

Bartstra, G.J. 1976. "Contribution to the study of the Palaeolithic Patjitan Culture, Java Indonesia. Dalam J.E. Van Lohuizen de Leeuw (Ed), Studies in South Asian Culture. E.J. Brill: Leiden.

Erdbrink, D.P. 1954. "Mesolithic Remains of the Sampung Stage in Java: Some Remark and additions", South Western Journal of Anthropology Vol. 10 (297-298).

Geldern, Robert van Heine 1945. "Prehistoric Research in the Netherlands Indies" Dalam Pieter Honig and F roms (Ed) Science and Scientists in the Netherlands Indies. The Riverside Press. New York City.

Heekeren, H.R. Van. 1954. "New investigations on the lower Palaeolithic Patjitan Culture in Java", Berita Dinas Purbakala, 1.

Heekeren, H.R. Van. 1972. "The Stone Age of Indonesia" VRI 1972: 61. The Hague - Martinus Nijhoff.

Heydar, Muhamad. 1989. Calon Beliung Situs Teleng, di Punung, Pacitan Analisis Teknologi Berdasarkan Data Temuan Permuakaan. Skripsi Sarjana Fakultas Sastra UGM. Belum diterbitkan.

Saejono, R.P. 1984. Sejarah Nasional Indonesia I Departemen Pendidikan dan Rebudayaan. Jakarta.

Widianto, Harry. 1989. Laporan Penelitian Arkeologi Situs Ngrijangan, Punung Pacitan. Balai Arkeologi Yogyakarta. Belum diterbitkan. 